\title{
DEVELOPMENTS IN CHINESE LABOR SITUATION
}

\author{
By George E. Anderson, \\ Consul-General, Hongkong.
}

The increasing cost of labor in the open ports of China, which has been noted particularly for the past five years and which is also felt to some extent in all producing centers of China without regard to their connection with foreign trade, seems to have assumed a critical turn with the political uncertainty and political changes which have been experienced during the past two years and a half. This certainly has been true of South China. In nearly all lines of industry wages have risen from five to twenty per cent in that part of China which is tributary in a trade way to Hongkong. In some cases the rise in wages has been sufficient to completely change conditions under which goods for export are produced and the change already is materially affecting trade with foreign nations, including the United States. In the matting trade, for example, the rise in wages has been such that in spite of the fact that the current season has developed no difficulty as regards supplies of straw, - the supply, in fact, has been better than usual - the cost of manufacture has so increased as to make it impossible for producers to make and ship goods at anything like the old rate. The cost of rattan furniture, blackwood furniture, fire-crackers and all similar products into which the cost of labor enters as the controlling element has advanced about ten per cent on an average. In industries supplying native needs, such as Chinese shoemaking, Chinese tailoring and hat making, furniture manufacture and the like, the advance has been from eight to twenty per cent. The price of household service has advanced from ten to twenty per cent and the difficulty of securing acceptable service at even the advanced rates is increasing. Wages of tailors on foreign work have advanced as much as twenty-five per cent, though this is accounted for largely by the increased demand for foreign style clothing. Wages of printers, carpenters, masons and all trade mechanics have advanced similarly. In all lines of labor the increase is manifest either in actual advance or in agitation and restlessness which represent prospective advance. 
The increased price of rice which has obtained over all the Far East in the past two years has had a marked influence upon these labor conditions, but there is no question that the chief element in the change has been in changing conditions in the Chinese labor world, and it is becoming more and more evident that the political changes in China are accompanied by economic changes which may as profoundly affect the country as other developments and which are likely to first affect foreign trade. The situation is opening up in a direct and practical way the entire question of the place Chinese labor is to have in the industries and trade of the world in the immediate future, and in a general way it is becoming evident that Chinese labor has advanced along the road of modern industrialism and that it is commencing to demand a return for its efforts which is more commensurate with that received by similar labor in other lands.

The mass of labor in China, of course, still remains in practically the same condition it was found by foreigners when China was first opened up to foreign trade. In the open ports and in those portions of the country in touch with foreign industry and trade and foreign ideas and appliances, this same labor has given and is now giving an indication of what the general advancement of China along modern lines means to Chinese labor. This advancement is shown in nearly all lines of modern industry, -in electrical enterprises and railways, in navigation, factory work, mining, milling and almost all similar lines. A review of the modern industrial work so far undertaken in China gives every assurance that the mass of the Chinese people as a whole will respond readily and effectively to the demands made upon them by modern industrialism. There are many reasons for believing that the industrial future of China now hinges more upon the higher training and thorough equipment, as well as the native ability of its educated classes, rather than upon the great mass of the people which must furnish the ordinary workmen for all modern industrial undertakings.

The experience of railway construction and operation in China to date has been such as to promise effective railway work. The chief engineer of the Kwangtung section of the Canton-Hankow railway line, now in partial operation the further construction of which is being pushed forward, reports that one of the most encouraging features of railway work in China is the readiness with which Chinese workmen grasp new ideas in mechanical lines. He has found that 
when once new apparatus is explained to them and its use demonstrated, they grasp not only its advantages but the practical principles upon which it operates. They may not understand the scientific reasons why a machine will do what it actually does, but they accept the fact that it does it and take advantage of it accordingly. In railway work they have been found to make good locomotive engineers, not only because of their ability to manage the locomotives on a track but because of their ability to grasp the details of locomotive construction and to care for the machines in a proper manner. They make good boiler makers, molders, car makers and shop men generally, and particularly are useful in general repair work. They also make good conductors and brakemen, good trackmen both as regards ordinary work and light engineering work, are skilful carpenters and bridgemen,-in short, they adapt themselves to all lines of railway work.

The Chinese workman has already proved his worth in many other lines of modern industrial effort. In Hongkong there are the two largest ship construction and repair concerns in Asia with the exception of certain modern yards in Japan. In these dock-yards Chinese workmen have shown themselves adaptable to all lines of technical work as machine men, molders, carpenters, plumbers, sail makers, workers in iron and brass, draughtsmen and all other lines of ship-building and repair work. In the operation of ships themselves the Chinese are among the best sailors in the world, and the fact that they are now rapidly supplanting European crews on most ships sailing in this portion of the world demonstrates their worth in practical lines of technical and general work aboard ship.

In Hongkong, Chinese chauffeurs drive automobiles with notable success. They are successful motorneers and conductors on street railways; they are successful stationery engineers; they are successful as repair men for motor boats, automobiles, handling modern motors of all kinds with success. Practically all the launches in the immense shipping interests in Hongkong are handled entirely by Chinese. In street railway work they are practical trackmen. They are practical road builders and handle modern steam rollers in such work. In Hongkong, Chinese workmen are successfully furnishing all labor, save chief superintendence, for glass factories, paper factories, rope works, candle factories, soap factories, canning factories, match factories, cement factories, shoe factories and other estab- 
lishments of the sort, many of the establishments having modern machinery and the latest economical appliances. Chinese workmen are successful expert repairers of sewing machines, typewriters, phonographs, watches, clocks, cameras and practically all lines of foreign machines and apparatus sold in the Far East.

Chinese workmen, as a rule, are economical of materials and careful of machinery. They are very careful of tools, use them skilfully and bear with imperfections which western workmen would not accept in tools or apparatus at all.

As a rule, northern Chinese workmen are considered the best among the Chinese, and yet it should be noted that the experience of the Hanyang Iron Company at Hankow has been that their best workmen are from Canton in the extreme south of the empire, their next best from Ningpo in central coast China, and their third best from their own province in mid-China. The Cantonese by centuries of training are unquestionably the best adapted, of all Chinese, to industrial life. Canton is to-day, and has been for years, the center of an industrial life which has few counterparts in the world. That city of perhaps a million and a half population is one great hive of industry and trade. Its industrial production, like that of all China, is from small shops and hand work, but the aggregate is enormous, while the industrial training given its people is one of the great assets of China in the modern industrial life the nation is now entering upon.

Nevertheless Chinese labor is not to be considered upon the same industrial basis as European or American labor. In mill work and similar employment it is generally rated at about ninety per cent of European efficiency and at about one-seventh the wage cost. In other lines its efficiency is not so great. Many things are to be considered in this connection and it is doubtful whether in the long run Chinese labor will be found much more than half as cheap as European labor, and as the country develops industrially it makes such new demands upon its people that wages must rise in proportion. This inevitable rise is the change which is now upon us. Probably the change will come by irregular advances with perhaps a reaction from time to time. It will probably proceed along lines similar to those followed by a similar change in Japan. It may be relied upon that China is to develop industrially to a more or less extent at once, and that its modern industries will be embarrassed in no way by a lack of 
intelligent and efficient labor at a reasonable price. But it is quite unlikely, both as a social and an economic proposition, that there will be any flood of Asiatic products in Europe and America as a result of such development. The country and people will do very well indeed if their industrial advancement can keep pace with the increase in their own demand for the products of such industrial development. 